\title{
Biochemical Characterization of Lipase Produced by Bacillus spp. Isolated from Soil and Oil Effluent
}

\author{
Afaf O. B. Shart, Elhadi A. I. Elkhalil* \\ Department of Botany and Agric. Biotechnology, Faculty of Agriculture, University of Khartoum, Shambat, Sudan \\ Email: ^eaikhalil@yahoo.com, *eaelkhalil@uofk.edu
}

How to cite this paper: Shart, A.O.B. and Elkhalil, E.A.I. (2020) Biochemical Characterization of Lipase Produced by Bacillus spp. Isolated from Soil and Oil Effluent. Advances in Enzyme Research, 8, 39-48. https://doi.org/10.4236/aer.2020.84004

Received: February 6, 2020

Accepted: December 26, 2020

Published: December 29, 2020

Copyright $\odot 2020$ by author(s) and Scientific Research Publishing Inc. This work is licensed under the Creative Commons Attribution International License (CC BY 4.0).

http://creativecommons.org/licenses/by/4.0/

\begin{abstract}
The aim of the present work was to isolate Bacillus spp. With high lipase activity; to characterize the isolates using both biochemical and molecular methods; to produce lipase using Bacillus isolates and to study the biochemical and biophysical characteristics of the produced lipase. Sixty five Bacillus isolates were isolated from soil 20 isolates from guar field soil (G), 15 isolates from Abusabein field soil (B), 15 isolates from sun flower field soil (S) and 15 isolates from oil effluent $(\mathrm{O})$. Lipase producing isolates were screened; a Chromogenic plate's method was used. Enzyme activity was quantitatively assayed. Lipase production under submerged fermentation (SMF) conditions using a production medium that contained metal salts, Tween-20 and olive oil as substrate at different period $24,48,72$ and $96 \mathrm{~h}$, the optimum $\mathrm{pH}$, temperature for lipase activity was determinated and kinetics as well. The isolates showed the highest lipase activity which was identified as Bacillus sp. The optimum $\mathrm{pH}$, temperature, thermostability and kinetic of the produced enzymes were found in three isolates $\mathrm{G} 14, \mathrm{O} 1$ and B10 with the highest enzyme activity and best stability. The isolates G14, O1 and B10 revealed the highest lipase activity of $63.4,41.2$ and $28.3 \mathrm{U} / \mathrm{ml}$, respectively. The results showed optimum $\mathrm{pH}$ of the lipase activity from isolates $\mathrm{G} 14, \mathrm{O} 1$ and B10 8.0, 6.0 and 6.0 and the optimum temperature 40,60 and $75^{\circ} \mathrm{C}$, respectively. Lipase enzymes from isolates $\mathrm{O} 1$ and $\mathrm{B} 10$ were found to be more thermostable after incubation time for $120 \mathrm{~min}$ at $90^{\circ} \mathrm{C}$. The $\mathrm{V}_{\max }$ and $\mathrm{K}_{\mathrm{m}}$ values of lipase for isolates G14, OI and B10 were 17.6, 135 and $24.4 \mu$ mole $\cdot \mathrm{min}^{-1}$ and 1.3, 1.6 and 0.681 $\mathrm{mM}$, respectively. According to these results Bacillus spp. with high lipase activity and thermostability can be used to promote food, pharmaceuticals, paper, detergents agrochemicals industries and pollution control in Sudan.
\end{abstract}

\section{Keywords}

Bacillus, Lipase, Biochemical Characterization, Oil Effluent 


\section{Introduction}

Lipases occur widely in nature, and microbial lipases such as bacterial lipases, fungal lipases and mold lipases are more favorable because of their low cost in production, greater stability and availability than plant and animal lipases. The lipases primarily carried out from fungi, molds or bacteria; and most of lipases formed extracellularly [1]. Lipases are considered to be the third biggest enzymes group following proteases and amylases, based on total sales volume. Because of its extensive range of applications lipase production is a billion dollar business [2]. Bacillus lipases have attracted much attention because of their biotechnological potential, which has led to the isolation of several lipolytic enzymes of Bacillus subtilis and other species of the genus Bacillus, Geo-bacillus and Paenibacillus [3]. Many applications of lipases include specialty organic syntheses, hydrolysis of fats and oils, modification of fats, flavor enhancement in food processing, resolution of racemic mixtures, and chemical analyses [4].

Lipases (Glycerol ester hydrolases E.C. 3.1.1.3) are much-demanded enzymes with significant commercial applications in industries. Lipases stimulate the hydrolysis of triacylglycerols to glycerol and free fatty acids. A real lipase will cleave emulsified esters of glycerin and lengthy chain fatty acids such as triolen and tripalmitin [5]. Lipases are widely used in the processing of fats and oils, detergents and diaries processing, the synthesis of fine chemicals and pharmaceuticals, paper industries and production of cosmetics [6]. Lipase-producing microorganisms have been found in different habitats such as industrial wastes, vegetable oil processing factories, dairies, soil contaminated with oil, etc. [7]. Microbial lipases detoxify and degrade the oil effluents as one by innovative technologies [8]. The present work aimed at Screening of Bacillus spp. producing lipase by using phenol red plate agar assay, identifying the isolates by using both biochemical and molecular methods (RAPD analysis), and to characterize the biochemical properties of the lipase.

\section{Materials and Methods}

\subsection{Sampling}

Fifty Soil samples were collected from Khartoum University farm in Shambat (Rhizosphere depth $10 \mathrm{~cm}$ of guar, Abusabein and sun flower fields), the soil was alkaline; pH 8.5 and was salty clay. In addition 15 samples were collected from effluent oil at the industrial area Omdurman. Each sample was placed into sterilized plastic package and transferred to laboratory and they kept at room temperature.

\subsection{Isolation of Bacillus Isolates}

Isolation of Bacillus was carried out according to [9]. $10 \mathrm{~g}$ from each sample were taken and dissolved in $90 \mathrm{ml}$ distilled water. Soil suspension was heated at $80^{\circ} \mathrm{C}$ for 15 minutes. The five dilutions of soil and effluent oil were made $\left(10^{-1}\right.$, $10^{-2}, 10^{-3}, 10^{-4}$, and $\left.10^{-5}\right)$. And 6 plates of nutrient agar for each sample were inoculated (by the spread plate method) with $0.1 \mathrm{ml}$ of heated dilutions $\left(10^{-3}, 10^{-4}\right.$, 
$10^{-5}$ ) and incubated aerobically in $37^{\circ} \mathrm{C}$ for 24 hours. Then colonies were purified and prepared for the further work.

\subsection{Conventional Identification of Bacillus Isolates}

Identification of pure culture of each Bacillus isolates was carried out according to [10] [11].

\subsection{Molecular Characterization of Bacterial Isolates}

Molecular RAPD Technique

DNA extraction from Bacillus isolates was carried out using a CTAB based protocol described by [12]. Classification of the isolates at the molecular level was carried out using RAPD-PCR technique according to [13]. By three Primer, (1) OPL3 (5-CCA GCA GCT T-3), Primer (2) OPL8 (5-AGC AGG TGG A-3), and Primer (3) OPQ1 (5-GGG ACG ATG G-3).

\subsection{Screening for Lipase Activity by Phenol Red with Olive Oil Plate Agar}

Typical Bacillus isolates was screened for producing lipase enzymes. Using chromogenic plate's assay, which was prepared as followed by [14]. using phenol red $(0.1 \%)$ along with $1 \%$ lipidic substrate olive oil, $10 \mathrm{mM} \mathrm{CaCl}_{2}$ and $2 \%$ agar $\mathrm{pH}$ is adjusted to $7.3-7.4$ using $0.1 \mathrm{~N} \mathrm{NaOH}$. Then, the plates were incubated with young culture $24 \mathrm{~h}$ from the different isolates then incubation for 7 days at $37^{\circ} \mathrm{C}$. After that the plates should be examined for change in color from pink to yellow.

\subsection{Lipase Enzyme Productions}

The enzyme was produced from the purified isolates that showed a positive reaction on olive oil/phenol red plates test. The tested strains were cultured at $37^{\circ} \mathrm{C}$ in $100 \mathrm{ml}$ Erlenmeyer flasks containing $50 \mathrm{ml}$ of, the broth of production media contained peptone $0.2 \%, \mathrm{NH}_{4} \mathrm{H}_{2} \mathrm{PO}_{4} 0.1 \%, \mathrm{NaCl} 0.25 \%, \mathrm{MgSO}_{4} \cdot 7 \mathrm{H}_{2} \mathrm{O}$ $0.04 \%, \mathrm{CaCl}_{2} \cdot 2 \mathrm{H}_{2} \mathrm{O} 0.04 \%$, Olive oil $2 \mathrm{ml}$ and Tween-20 2 to 3 drops. One loop full of bacterial culture was inoculated in each flask and incubated at $37^{\circ} \mathrm{C}$. The $\mathrm{pH}$ was adjusted at $\mathrm{pH}$ 7. Lipase was extracted according to [15], from the production medium after incubation period $(24,48,72$ and $96 \mathrm{~h}$ ) by centrifugation at $6000 \mathrm{rpm}$ for $10 \mathrm{~min}$.

\subsection{Assay of Lipase Enzyme}

Lipase activity was assayed according to [16], with slightly modification, using p-nitro phenyl palmitate (p-NPP) as substrate. Enzyme solution $(50 \mu \mathrm{l})$ was added to $950 \mu \mathrm{l}$ of the substrate solution consisting of one part solution A (3.0 $\mathrm{mM}$ pNPP in 2-propanol) and nine parts solution B (100 mM potassium phosphate buffer $\mathrm{pH} 7.0,0.4 \%$ Triton $\mathrm{X}-100$ and $0.1 \%$ gum arabic), which was freshly prepared before use. The reaction mixture was incubated at $37^{\circ} \mathrm{C}$ for $20 \mathrm{~min}$ and absorbance was read at $410 \mathrm{~nm}$. Lipase activity and specific activities was calculated as the following formula: 


$$
\text { Lipase activity }(\mathrm{U} / \mathrm{ml})=\frac{A * B}{C * D * E}
$$

where,

$$
\begin{aligned}
& A-\mu \mathrm{mol} \text { of p-Nitro phenol released; } \\
& B-\text { Total volume; } \\
& C-\text { Volume used in spectrophotometric determination; } \\
& D-\text { Volume of enzyme used in assay; } \\
& E-\text { Time of incubation. }
\end{aligned}
$$

\subsection{Characterization of Lipase Enzyme}

\subsection{1. pH Optimum}

Substrate solution was prepared in $100 \mathrm{mM}$ phosphate buffer at $\mathrm{pH} 4,5,6,7$ and 8 according [7]. The reaction mixture consisted of $50 \mu$ enzyme extract and 950 $\mu \mathrm{l}$ of substrate solution, before incubation the mixture adjusted to desired $\mathrm{pH}$ by using $\mathrm{HCl}$ or $\mathrm{NaOH}$. The reaction mixture was incubated for $20 \mathrm{~min}$ at $37^{\circ} \mathrm{C}$ and then the optical density (O.D) was determined at $410 \mathrm{~nm}$.

\subsubsection{Temperature Optimum}

For determining the optimum temperature [17]; with slightly modification the reaction mixture was prepared as described above. The $\mathrm{pH}$ mixture corresponded to determined optimum $\mathrm{pH}$ of the respective enzyme. The mixtures were incubated for $20 \mathrm{~min}$ at each of the following temperature; $40^{\circ} \mathrm{C}, 45^{\circ} \mathrm{C}$, $50^{\circ} \mathrm{C}, 55^{\circ} \mathrm{C}, 60^{\circ} \mathrm{C}, 65^{\circ} \mathrm{C}, 70^{\circ} \mathrm{C}, 75^{\circ} \mathrm{C}, 80^{\circ} \mathrm{C}, 85^{\circ} \mathrm{C}$, or $90^{\circ} \mathrm{C}$, after that lipase activity was determined as described before.

\subsubsection{Determination of Thermostability}

The thermostability was determined in aqueous solution [17]. With slightly modification, The lipase preparation were pre incubated at $50^{\circ} \mathrm{C}, 60^{\circ} \mathrm{C}, 70^{\circ} \mathrm{C}$, $80^{\circ} \mathrm{C}$, or $90^{\circ} \mathrm{C}$ for $10,20,30,40,50,60,70,80,90,100,110$, or $120 \mathrm{~min}$ after pre incubation periods, the samples were cooled and they were incubated at optimum temperature determined of the respective enzyme and the activities of enzymes were estimated as described before.

\subsection{Enzyme Kinetics}

Michaelis-Menten constant for lipase substrate pNPP was determined according to [18]. With some modification pNPP instead pNPL (p-nitropheny laurate) and concentration by incubating with concentrations of substrate ranging from 0.05 to $5.0 \mathrm{mmol} / \mathrm{l}$ with lipase from three have chosen isolates. The value of constant was calculated according to the Hanes-Woolf plot.

\section{Results and Discussion}

\subsection{Screening for Lipase Activity by Phenol Red with Olive Oil Plate Agar}

AII isolate subjected to chromogenic plates assay; isolates were showed a positive 
result to the test by convert the color of medium from red to yellow indicate that lipase was produced by different Bacillus strains. The free fatty acids liberated by the lipolysis organisms lower the $\mathrm{pH}$ resulting in the change of color indicating the formation of lipase [19]. Therefore the isolates were found to be a lipase producer, capable of utilizing the substrate (olive oil) to produce yellow color zone. This result agreed with [20] [21], they proved that the use of phenol red in lipase assay was highly reproducible with sensitivity level as low as 0.5 p-nitrophenyl palmitate (p-NPP) enzyme units within $15 \mathrm{~min}$. Therefore, by using olive oil as the lipidic substrates in phenol red agar, the presence of lipolysis activity could be indicated by the yellow coloration. This assay is based on the principle where free fatty acids were released from the bacterial lipolysis reaction. Lipase from Bacillus isolates was produced in liquid production medium. As a more accurate, quantitative method to support chromogenic plates assay for use in screening for Bacillus producing lipase. The lipase activities of isolates ranged between $3.4 \mathrm{U} / \mathrm{ml}$ (isolate O3) to $63.4 \mathrm{U} / \mathrm{ml}$ isolate G14 (Table 1). Among the tested isolates, three isolates B10, O1 and G14 showed high potential in Lipase production and had an average lipase activity of 28.3, 41.2 and 63.4 Unit/ml, respectively.

Table 1. Lipase activity and optimum incubation periods of different isolates.

\begin{tabular}{|c|c|c|c|}
\hline Isolates & Sources & Lipase activity $(\mathrm{U} / \mathrm{ml})$ & Optimum time of incubation (hour) \\
\hline S1 & Sun flower Soil & 8.8 & 24 \\
\hline S2 & Sun flower Soil & 39.9 & 72 \\
\hline S3 & Sun flower Soil & 35.2 & 72 \\
\hline S5 & Sun flower Soil & 35.2 & 72 \\
\hline S12 & Sun flower Soil & 12.6 & 96 \\
\hline B4 & Abusabein Soil & 27.0 & 48 \\
\hline B7 & Abusabein Soil & 61.2 & 48 \\
\hline B8 & Abusabein Soil & 16.4 & 72 \\
\hline B10 & Abusabein Soil & 28.3 & 72 \\
\hline O1 & Oil waste & 41.2 & 72 \\
\hline $\mathrm{O} 2$ & Oil waste & 26.9 & 48 \\
\hline $\mathrm{O} 3$ & Oil waste & 3.4 & 24 \\
\hline $\mathrm{O} 4$ & Oil waste & 12.8 & 72 \\
\hline O9 & Oil waste & 23.6 & 48 \\
\hline $\mathrm{O} 12$ & Oil waste & 5.7 & 24 \\
\hline G2 & Guar Soil & 28.7 & 72 \\
\hline G4 & Guar Soil & 52.4 & 48 \\
\hline G5 & Guar Soil & 43.6 & 48 \\
\hline G6 & Guar Soil & 5.9 & 96 \\
\hline G7 & Guar Soil & 17.4 & 96 \\
\hline G8 & Guar Soil & 28.2 & 72 \\
\hline G10 & Guar Soil & 19.8 & 48 \\
\hline G11 & Guar Soil & 31.1 & 96 \\
\hline G14 & Guar Soil & 63.4 & 48 \\
\hline G15 & Guar Soil & 24.4 & 72 \\
\hline
\end{tabular}




\subsection{Biochemical and Biophysical Characteristics}

\subsection{1. pH Behavior}

The $\mathrm{pH}$ optima of lipase from isolates O1, B10 and G14 (Figure 1) were determined by exposing lipases to a range of $\mathrm{pH}$ conditions. The $\mathrm{pH}$ optima of each lipase preparations from each isolate and the $\mathrm{pH}$ behavior of different lipase preparation are shown in Figure 1. The $\mathrm{pH}$ optima of lipase from isolates (O1, B10 and G14) are found to be ranged between 4 and 9. The highest activities of lipase for each isolates were measured at $\mathrm{pH} 6.0$ and 8.0. This result is agreement with the previously reports for lipase optimum $\mathrm{pH}$ of Bacillus pumilus RK31 at $\mathrm{pH} 6.0$ [7], Bacillus subtilis $K-L$ at $\mathrm{pH} 8.0$ [22]; However change in $\mathrm{pH}$ has a varied effect on enzyme activity, through altering the structure of enzyme and substrate and inhibiting the catalysis of reaction [17].

\subsubsection{Optimum Temperature}

The optimum temperature of the lipase results were shown in Figure 2. The activities of each lipase from the different isolates after incubation with pNPP solution under different temperature degree for $20 \mathrm{~min}$ were mentioned in Figure 2. Isolate $\mathrm{O} 1$ lipases displayed a highest activity at $60^{\circ} \mathrm{C}$ while isolate $\mathrm{B} 10$ and

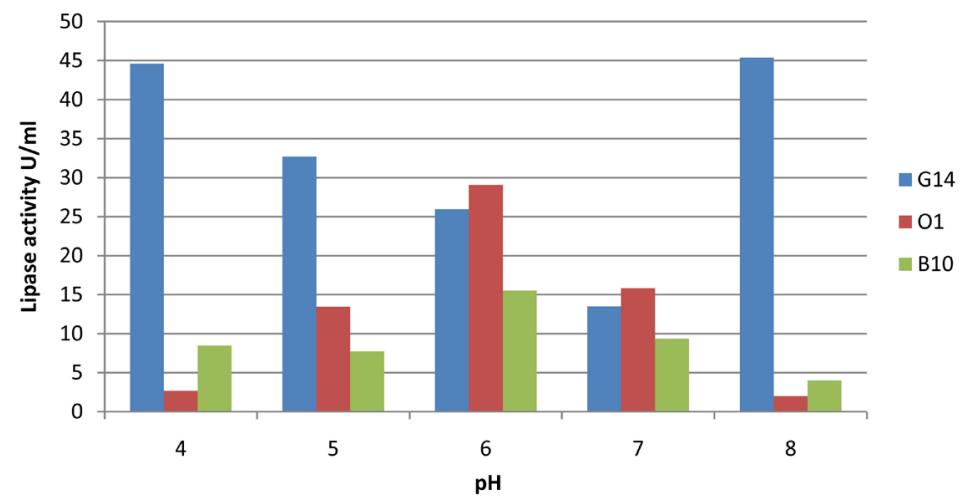

Figure 1. $\mathrm{pH}$ behavior of lipase preparations produced from three Bacillus isolates. Where, G14 = bacteria isolated from Guar field O1 = bacteria isolated from Oil effluent $\mathrm{B} 10=$ bacteria isolated from Abusabein field.

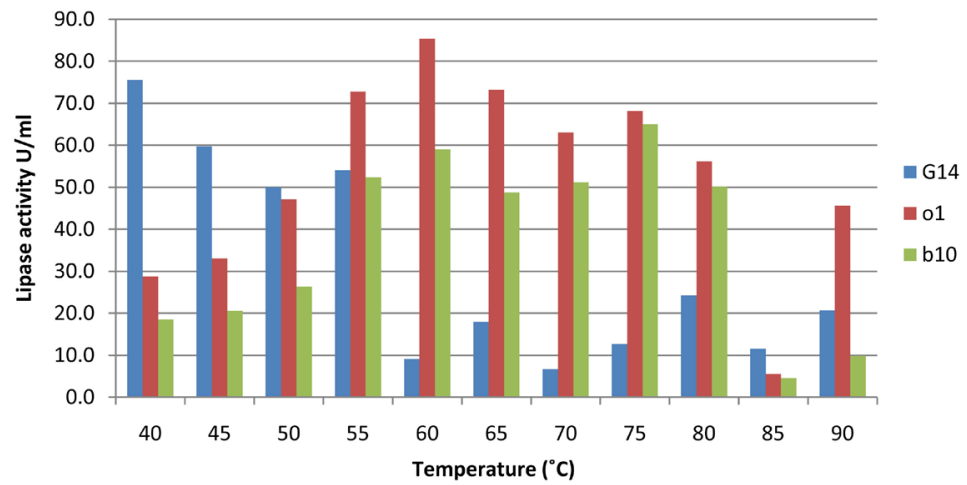

Figure 2. Temperature profile of lipase preparations produced from three Bacillus isolates. Where, G14 = bacteria isolated from Guar field O1 = bacteria isolated from Oil effluent B10 = bacteria isolated from Abusabein field. 
isolate G14 released their highest activity at $75^{\circ} \mathrm{C}$ and $40^{\circ} \mathrm{C}$ respectively. The optimum temperature for a lipase production from Staphylococcus epidermis (MTCC 10656) was $40^{\circ} \mathrm{C}$ [23], while from Bacillus coagulans was $40^{\circ} \mathrm{C}$ [24] and from Bacillus sp was $60^{\circ} \mathrm{C}$ [18] [25], as the reported that the optimum temperature for a lipase production from Bacillus sp. H-257 and Bacillus thermoleovorans ID-1 was $75^{\circ} \mathrm{C}$ by [26] [27]; similarity to the results of the ongoing study are in line with that of previous studies.

\subsubsection{Thermostability of Lipases}

The thermostability of lipases was measured in aqueous solutions at the optimum temperature of each enzyme; (see Figures 3-5) show the lipase activity of the preparation after exposure for different periods at $50^{\circ} \mathrm{C}, 60^{\circ} \mathrm{C}, 70^{\circ} \mathrm{C}, 80^{\circ} \mathrm{C}$ and $90^{\circ} \mathrm{C}$. After incubation time for $120 \mathrm{~min}$ at $90^{\circ} \mathrm{C}$ lipase from isolate $\mathrm{G} 14$ was completely inactivated, while lipase from isolate $\mathrm{O} 1$ lost activity after $90 \mathrm{~min}$ but it retain activity within $100 \mathrm{~min}$. also lost activity in $80^{\circ} \mathrm{C}$ and retain activity in $90 \mathrm{~min}$. lipase from isolate $\mathrm{B} 10$ lost activity in $80 \mathrm{~min}$ at $90^{\circ} \mathrm{C}$ and retain activity in $90 \mathrm{~min}$. At all temperature examined three isolate showed high activities. The thermo stability of the lipase at high temperature indicates its suitability for industrial applications and commercialization, because of unique nature of protein and its thermostable nature [17].

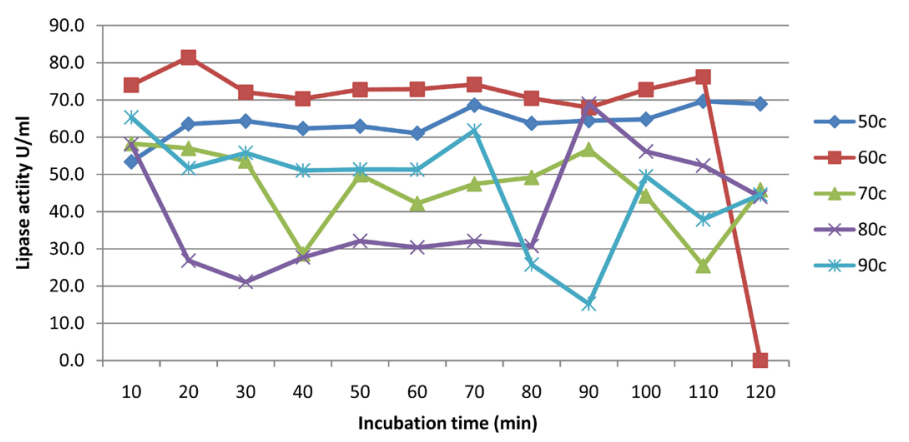

Figure 3. Enzyme activities of lipase preparation from isolate $\mathrm{O} 1$ after exposure for different periods at different temperature. That data are expressed as activity at the optimum temperature for $20 \mathrm{~min}$.

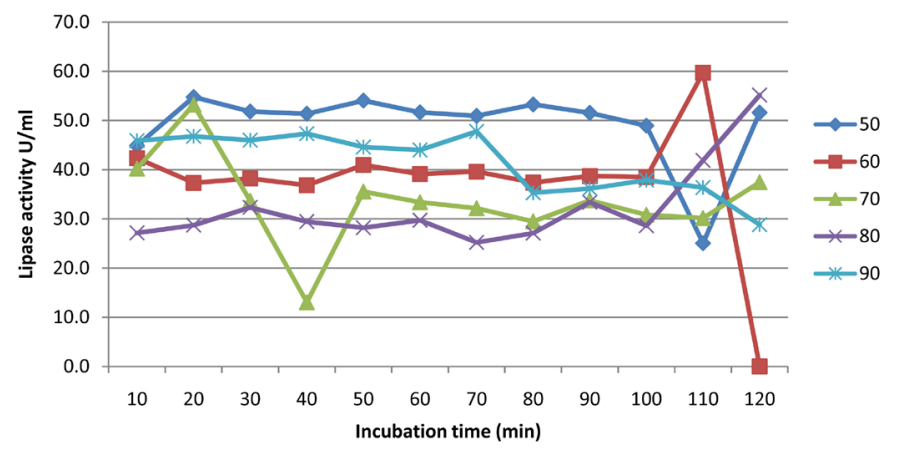

Figure 4. Enzyme activity of lipase preparation from isolates B10 after exposure for different periods at different temperature. That data are expressed as activity at the optimum temperature for $20 \mathrm{~min}$. 


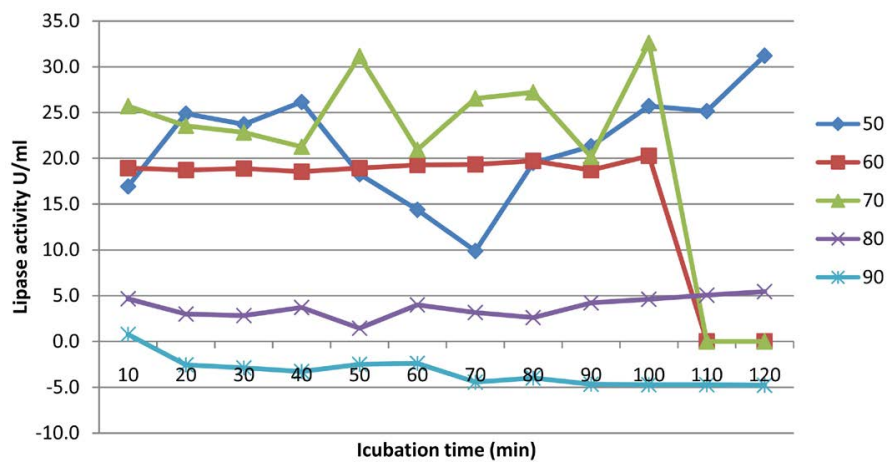

Figure 5. Enzyme activity of lipase preparation from isolates G14 after exposure for different periods at different temperature. That data are expressed as activity at the optimum temperature for $20 \mathrm{~min}$.

\subsection{Lipase Kinetics}

The lipase kinetics from Bacillus isolates O1, B10 and G14 were measured at the $\mathrm{pH}$ and temperature optima of the respective lipase in $0.01 \mathrm{M}$ potassium phosphate buffer and in different $\mathrm{pNPP}$ concentration as substrate $(0.05,0.5,1.0,2.5$ and $5 \mathrm{mM}$ ). The $\mathrm{V}_{\max }$ and $\mathrm{K}_{\mathrm{m}}$ values of lipase from isolates $\mathrm{G} 14$, OI and B10 were 17.6, 135 and $24.4 \mu \mathrm{mole} / \mathrm{min}$ and 1.3, 1.6 and $0.681 \mathrm{mM}$, respectively. [28] found that $\mathrm{K}_{\mathrm{m}}$ and $\mathrm{V}_{\max }$ values of the lipase purified from Bacillus Stearothermophilus HU1 of $0.235 \mathrm{mM}$ and $161.2 \mathrm{mmol} / \mathrm{min} / \mathrm{mL}$, respectively, as the reported by [29] $\mathrm{K}_{\mathrm{m}}$ and $\mathrm{V}_{\max }$ values, were $105.26 \mathrm{mmol}$ and $0.116 \mathrm{mmol} \cdot \mathrm{min}^{-1} \cdot \mathrm{g}^{-1}$, respectively from Bacillus sp. ITP-001 using olive oil as the substrate.

\section{Conclusion}

Bacillus is clearly identified using morphological, biochemical and molecular methods (RAPD-PCR). The maximum lipase activity was found to be $63.4 \mathrm{U} / \mathrm{ml}$ from isolate G14 (isolate from guar soil), after incubation period of 48 hours. The $\mathrm{pH}$ optimum of the isolates $\mathrm{O} 1$ and $\mathrm{B} 10$ are acidic $(\mathrm{pH} 6)$ and $\mathrm{G} 14$ is alkaline $(\mathrm{pH} 8)$. Isolate $\mathrm{B} 10$ is more lipase active at the optimum temperature of $75^{\circ} \mathrm{C}$, this will make it more suitable for producing lipase to use in detergent industry or all that industries depend on higher temperature. Isolate G14 showed the lowest stability after heat treatment in $90^{\circ} \mathrm{C}$. Lipases from isolates G14, OI and $\mathrm{B} 10$ have $\mathrm{V}_{\max }$ values of 17.6, 135 and $24.4 \mu \mathrm{mole} / \mathrm{min}$ and $\mathrm{Km}$ values of 1.3 , 1.6 and $0.618 \mathrm{mM}$, respectively.

\section{Conflicts of Interest}

The authors declare no conflicts of interest regarding the publication of this paper.

\section{References}

[1] Aravindan, N.R., Anbumathi, P. and Viruthagiri, T. (2007) Lipase Applications in Food Industry. Indian Journal of Biotechnology, 6, 141-158.

[2] Jaeger, K.E., Dijkstra, B.W. and Reetz, M.T. (1998) Bacterial Biocatalysts: Molecular 
Biology Three Dimensional Structures and Biotechnological Applications of Lipases. Annual Review of Microbiology, 53, 315-351. https://doi.org/10.1146/annurev.micro.53.1.315

[3] Gupta, R., Gupta, N. and Rathi, P. (2004) Bacterial Lipases: An Overview of Production, Purification and Biochemical Properties. Applied Microbiology and Biotechnology, 64, 763-781. https://doi.org/10.1007/s00253-004-1568-8

[4] Sharma, R., Chisti, Y. and Banerjee, U.C. (2001) Production, Purification, Characterization, and Applications of Lipases. Biotechnology Advances, 19, 627-662. https://doi.org/10.1016/S0734-9750(01)00086-6

[5] Gayathri, V.R., Perumal, P., Mathew, L.P. and Prakash, B. (2013) Screening and Molecular Characterization of Extracellular Lipase Producing Bacillus Species from Coconut Oil Mill Soil. International Journal of Science and Technology, 2, 502-509.

[6] Tambekar, D.H., Kalikar, M.V., Shinde, R.S., Vanjari, L.B. and Pawar, R.G. (2009) Isolation and Characterization of Multiple Enzyme Producer Bacillus Species from Saline Belt of Purna River. Journal of Applied Sciences Research, 5, 1064-1066.

[7] Kumar, R., Sharma, A., Kumar, A. and Singh, D. (2012) Lipase from Bacillus pumiIus RK31: Production, Purification and Some Properties. World Applied Sciences Journal, 16, 940-948.

[8] Kumar, M.D.J., Rejitha, R., Devika, S., Balakumaran, M.D.A., Immaculate, A., Rebecca, N. and Kalaichelvan, P.T. (2012) Production, Optimization and Purification of Lipase from Bacillus sp. MPTK 912 Isolated from Oil Mill Effluent. Advances in Applied Science Research, 3, 930-938.

[9] Lindquist, J. (2006) Bacillus Isolation. Bacteriology 102 Website-Fall.

[10] Claus, D. and Berkeley, R.C.W. (1986) Genus Bacillus Cohn, 1872. In: Sheath, P.H.A., Mair, N.S., Sharpe, M.E. and Holt, J.G., Eds., Bergey's Manual of Systematic Bacteriology, Vol. 2, The Williams and Wilkins Co., Baltimore, 1105-1139.

[11] Harrigan, W.F. (1998) Part IV: Schemes for the Identification of Microorganisms. Academic Press, London, Laboratory Methods in Food Microbiology, 3rd Edition, 469.

[12] Muruke, M.H.S., Kivaisi, A.K., Magingo, F.S.S. and Danell, E. (2002) Identification of Mushroom Mycelia Using DNA Techniques. Tanzania Journal of Science, 28, 115-128. https://doi.org/10.4314/tjs.v28i1.18323

[13] Williams, J.G.K., Kubelik, A.R., Livak, K.J., Rafalski, J.A. and Tingey, S.V. (1990) DNA Polymorphisms Amplified by Arbitrary Primers are Useful as Genetic Markers. Nucleic Acids Research, 18, 6531-6535. https://doi.org/10.1093/nar/18.22.6531

[14] Beisson, F., Tiss, A., Riviere, C. and Verger, R. (2000) Methods for Lipase Detection and Assay: A Critical Review. European Journal of Lipid Science and Technology, 102, 133-153.

https://doi.org/10.1002/(SICI)1438-9312(200002)102:2<133::AID-EJLT133>3.0.CO; $\underline{2-\mathrm{X}}$

[15] Poddar, S. and Singha, P. (2015) Isolation and Characterization of an Extracellular Lipase Producing Bacillus Corynebacterium sp. from Petroleum Contaminated Soils. Helix, 3, 699-703.

[16] Iftikhar, T., Naiz, M., Afzal, M., ul Haq, I. and Rajoka, M.I. (2008) Maximization of Intracellular Lipase Production in a Lipase-Overproducing Mutant Derivative of Rhizopus oligosporus DGM 31: A Kinetic Study. Food Technology and Biotechnology, 46, 402-412.

[17] Sharma, P., Sharma, N., Pathania, S. and Handa, S. (2017) Purification and Charac- 
terization of Lipase by Bacillus methylotrophicus PS3 under Submerged Fermentation and Its Application in Detergent Industry. Journal of Genetic Engineering and Biotechnology, 15, 369-377. https://doi.org/10.1016/j.jgeb.2017.06.007

[18] Ghori, M.I., Iqbal, M.J. and Hameed, A. (2011) Characterization of a Novel Lipase from Bacillus sp. Isolated from Tannery Wastes. Brazilian Journal of Microbiology, 42, 22-29. https://doi.org/10.1590/S1517-83822011000100003

[19] Singh, R., Gupta, N., Goswami, V.K. and Gupta, R. (2006) A Simple Activity Staining Protocol for Lipases and Esterases. Applied Microbiology and Biotechnology, 70, 679-682. https://doi.org/10.1007/s00253-005-0138-Z

[20] Lee, L.P., Karbul, H.M., Citartan, M., Gopinath, S.C.B., Lakshmipriya, T. and Tang, T.H. (2015) Lipase-Secreting Bacillus Species in an Oil-Contaminated Habitat: Promising Strains to Alleviate Oil Pollution. BioMed Research International, 2015, Article ID: 820575. https://doi.org/10.1155/2015/820575

[21] Rai, B., Shrestha, A., Sharm, S. and Joshi, J. (2014) Screening, Optimization and Process Scale Up for Pilot Scale Production of Lipase by Aspergillus niger. Biomedicine and Biotechnology, 2, 54-55.

[22] Saraswat, R., Verma, V., Sistla, S. and Bhushan, I. (2017) Evaluation of Alkali and Thermotolerant Lipase from an Indigenous Isolated Bacillus Strain for Detergent Formulation. Electronic Journal of Biotechnology, 30, 33-38.

https://doi.org/10.1016/j.ejbt.2017.08.007

[23] Edupuganti, S., Parcha, L. and Mangamoori, N.L. (2017) Purification and Characterization of Extracellular Lipase from Staphylococcus epidermidis (MTCC 10656). Journal of Applied Pharmaceutical Science, 7, 057-063. https://doi.org/10.7324/JAPS.2017.70108

[24] Alkan, H., Baysal, Z., Uyar, F. and Dogru, M. (2007) Production of Lipase by a Newly Isolated Bacillus coagulans under Solid-State Fermentation Using Melon Waste. Applied Biochemistry and Biotechnology, 136, 183-192. https://doi.org/10.1007/BF02686016

[25] Bora, L. and Bora, M. (2012) Optimization of Extracellular Thermophilic Highly Alkaline Lipase from Thermophilic Bacillus sp. Isolated from Hot Spring of Arunachal Pradesh, India. Brazilian Journal of Microbiology, 43, 30-42. https://doi.org/10.1590/S1517-83822012000100004

[26] Cho, A.R., Yoo, S.K. and Kim, E.J. (2000) Cloning, Sequencing and Expression in Escherichia coli of a Thermophilic Lipase from Bacillus thermoleovorans ID-1. FEMS Microbiology Letter, 186, 235-238. https://doi.org/10.1111/j.1574-6968.2000.tb09110.x

[27] Imamuri, S. and Kitaura, Sh. (2000) Purification and Characterization of a Monoacylglycerol Lipase from the Moderately Thermophilic Bacillus sp. H-257. Journal of Biochemistry, 127, 419-425. https://doi.org/10.1093/oxfordjournals.jbchem.a022623

[28] Massadeh, M., Sabra, F., Dajani, R. and Arafat, A. (2012) Purification of Lipase Enzyme Produced by Bacillus stearothermophilus HU1. International Conference on Eco-Systems and Biological Sciences, Penang, Malaysia, 19-20 May 2012, 34-37.

[29] Barbosa, J.M.P., Souza, R.L., de Melo, C.M., Frisks, A.T., Lima, A.S. and Soares, C.M.F. (2012) Biochemical Characterization of Lipase from A New Strain of Bacillus sp. ITP-001. Quimica Nova, 35, 1173-1178. https://doi.org/10.1590/S0100-40422012000600020 